Abstracta Iranica Abstracta Iranica

Revue bibliographique pour le domaine irano-aryen

Volume 40-41 | 2019

Comptes rendus des publications de 2017-2018

\title{
David J. Roxburgh, Mary McWilliams. Technologies of the Image. Art in 19th-Century Iran
}

\section{Iván Szántó}

\section{(2) OpenEdition \\ 1 Journals}

\author{
Electronic version \\ URL: http://journals.openedition.org/abstractairanica/50587 \\ DOI: 10.4000/abstractairanica.50587 \\ ISBN: 1961-960X \\ ISSN: 1961-960X \\ Publisher: \\ CNRS (UMR 7528 Mondes iraniens et indiens), Éditions de l'IFRI
}

Electronic reference

Iván Szántó, "David J. Roxburgh, Mary McWilliams. Technologies of the Image. Art in 19th-Century Iran", Abstracta Iranica [Online], Volume 40-41 | 2019, document 14, Online since 30 December 2019, connection on 19 April 2021. URL: http://journals.openedition.org/abstractairanica/50587 ; DOI: https://doi.org/10.4000/abstractairanica.50587

This text was automatically generated on 19 April 2021.

Tous droits réservés 


\title{
David J. Roxburgh, Mary McWilliams. Technologies of the Image. Art in 19th-Century Iran
}

\author{
Iván Szántó
}

\section{REFERENCES}

David J. Roxburgh, Mary McWilliams. Technologies of the Image. Art in 19th-Century Iran. Cambridge, MA - New Haven, CT: Harvard Art Museums / Yale University Press, 2017, p. 173, ISBN: 9781891771736 (Harvard) / 9780300229196 (Yale)

1 The volume accompanied an exhibition which was held at the Harvard Art Museums, Cambridge, Massachusetts, between 26 August 2017 until 7 January 2018. As a catalogue, it records 77 items exhibited (pp.131-157), while it also contains a collection of essays recreating the concept of the exhibition. The exhibition, in turn, was brought about by the joint display of Qajar artworks from the businessman-politician Kazem Kooros's (1906-2010) collection, by courtesy of his heirs, the donation of Ezzat-Malek Soudavar's (1913-2014) rich Qajar collection to the Harvard Art Museums by the deceased collector's son, Abolala Soudavar (another part of the material was donated to the Smithsonian Institution, Washington), and the long-term loan of an album of Qajar photographs, taken by 'Alī Khān Valī (1846-1902). Beyond the mere display of these manuscripts, lacquerworks, lithographs, and photographs, the exhibition aimed to demonstrate the resurgence of Persian image-making during the Qajar period through a creative interaction with Western techniques, something which has been explored by other recent exhibitions as well, notably Artisans at the Crossroads (Budapest, 2010).

2 In chapter 1 (“Technologies of the Image: Art in 19 ${ }^{\text {th }}$-Century Iran", pp. 3-22), David J. Roxburgh surveys all the above-mentioned media and points out that what has often been seen by Western observers of Qajar art as redundancy and slavish dependence on local and foreign models was in fact an "insistent contemporaneity" ready to juxtapose, 
interact with, and transform these models. Mary McWilliams in "Qajar Lacquer as a Medium of Exchange" (pp. 25-52) argues for the wide market spectrum of lacquer that made a plethora of genuine artworks available for middle-class clientele and royals in the same way as it was within easy reach of locals and visitors alike. Regarding artists, their work attests to their engagement in a vivid dialogue with local pasts and international contemporaneity, everyday life and epic deeds. In fact, some lacquer objects at the exhibition exemplify Russian-made mass-produced items showing European imagery, specifically marketed in Iran. The next chapter, by Farshid Emami ("The Lithographic Image and Its Audiences", pp. 55-79), re-examines the transition of handmade books, including the Šăhnāma, to printed volumes, the role these volumes played in the dissemination of pictorial ideas in other media, and the profound change of perception and intensely growing publicity of these texts and images. The consequences were even more dramatic with the early arrival and rapid spread of photography in Iran, as discussed by Mira Xenia Schwerda in chapter 4 ("Iranian Photography: From the Court, to the Studio, to the Street", pp. 81-105, which follows the trajectory of this new medium starting with the phase when it recorded a prephotographic society to another one when it took centre-stage to transform this society and its self-reflection. This chapter also distinguishes between the practitioners of different photographic techniques, different social statuses of photographers (i.e., members of the court, Armenians, etc.), as well as professional as opposed to amateur enthusiasts, like "Alī Khān Valī. The final chapter ("Painting after Photography in 19thcentury Iran", pp.107-130), by David Roxburgh, returns to the question of traditionalism vs. modernity, hailing Qajar art for its innovations while simultaneously condemning a great deal of past and present Western scholarship for their alleged prejudices and lack of understanding of the "complex intersections of mediums as well as their remediation."

\section{AUTHORS}

\section{IVÁN SZÁNTÓ}

Eötvös Loránd University, Budapest 